\title{
CORRESPONDENCE
}

\section{Human Embryology}

SIR,-Edwards and Sharpe (Nature, 231, 87 ; 1971) assert that "The common law of early centuries dealt only with either the "mother or fully delivered child'," citing Coke thereto.

I know of no better authority than Coke as to the general tenor of the law save the written law itself, which, standing "since the mind of man runneth not to the contrary", is assimilated to the common law, and is explicit; Alf. c 58 (sometime numbered c 9); "Be tham thæt man ofslea wif mid cilde: Yif mon wif mid bearne ófslea thonne thæt bearn in hire sie, foryielde thone wifman fullan yielde, \& thæt bearn be thæs fædrencnosles were healfan yelde", which I transcribe as "By them that wrongfully strike wife with child: If anyone cast down wife with bairn when that bairn be in her, then yield for the woman full compensation, and for that bairn half the compensation due in respect of the father's kin".

Yours faithfully,

TOM POPLETT

3 Bernhard Baron Cottages,

Polegate,

Sussex

\section{Smoke Without Fire}

Sir,-Your article "Smoke Without Fire" (Nature, 230, 418; 1971) contained a useful analysis of the current situation relative to a Comprehensive Nuclear Test Ban Treaty. The opportunities for achieving such a treaty appear better now than at any time since 1963, and it would serve as a useful complement to a SALT agreement in limiting nuclear arsenals.

However, your article was seriously marred by the concluding sentence which stated that such a treaty would do away with the need for IAEA inspection to verify compliance with the Non-Proliferation Treaty. Unfortunately this is not so. A non-nuclear weapons nation that had unsafeguarded fissionable material could proceed with a nuclear weapons programme without carrying out any nuclear tests. A simple atomic bomb could be developed today without any nuclear explosions, provided fissionable material was available. The basic weapons design principles are well known, and most of the detailed engineering can be confirmed without an actual nuclear test. No nation has yet had a failure in its first atomic test.

Therefore, IAEA safeguards on fissionable material produced in peaceful programmes are essential if proliferation is to be controlled. There is no basis for saying that these are an international hazard in their own right. They are being developed by the IAEA in a manner to avoid compromise of industrial secrets, and the US and the UK governments have voluntarily agreed to accept them even though not required to do so by the NPT.

\section{Yours faithfully,}

Herbert SCOVille JUN.

6400 Georgetown Pike, McLean, Virginia 22101

\section{Graduate Footballers}

SIR,--For a regular, albeit non-scientific, reader to find an error in Nature is almost as profound a shock as if the mistake had been committed by nature herself. Yet there they are--not one error, but two, and in the same sentence in the same leader: "No Dole at the Top" (Nature, 231, 70; 1971).

To call that astonishing professional newcomer Michael when everyone within 10 miles of north London let alone Liverpool must know he is Mr Steve Heighway is bad enough, but then you add insult to the injured sensibilities of all football addicts by proclaiming him "the only professional footballer in Britain to have been to university and to have come away with a degree". Oh, sir, and it is his very own teammate, Mr Brian Hall, who gives you the lie.

Yours faithfully,

Richard B. Fisher

26 St Paul's Road, London N1

\section{Labour Rewarded}

SiR,-Why should it be thought natural ${ }^{1}$ to assume that an animal will prefer to obtain food without work? To me it seems much more reasonable to suppose that the work which normally accompanies an animal's search for food should be enjoyable to the animal. It may at times even be performed with the full knowledge that it will not lead to food. For surely enjoyment of an animal's necessary functions has a high survival value.

With dogs growling naturally goes with the taking of food; it is, in the sense in which the word is used here, work. It is obvious that dogs enjoy it and indulge in it even when food is not expected. My dog will often, though apparently hungry, refuse to touch his food until I have made a symbolic gesture of taking it away from him, whereat he will growl and fall to. His wagging tail proclaims his enjoyment. Yours faithfully, H. H. Clayton

75 Glendale Avenue,

Deep River, Ontario

1 Nature, 229, 89 (1971).

Our experimental psychology correspondent comments:

One of the principles that has been used, explicitly or implicitly, in explaining how animals come to learn certain tasks is that they attempt to minimize the effort expended. So although the point that animals are adapted to working for their food is certainly a reasonable one, there remains the question as to why an animal chooses the shorter of two routes through a maze, or comes to prefer the less onerous of two reinforcement schedules. The assumption that he is minimizing effort may of course be quite wrong; an alternative index that the animal might use is the time between starting a trial and achieving reward. It is in any case an empirical question, and the recent experiments on preferences for working over receiving free food demonstrate that there is a problem. Quite apart from any theoretical issue that might be involved, I think that few people would predict that an animal or person would invariably choose the more laborious of two alternative means of achieving a goal. 